\title{
HALAL TOURISM OPPORTUNITIES AND CHALLENGES IN EAST JAVA
}

\author{
Otto Andri Priyono \\ Program Studi Magister Manajemen, Fakultas Ekonomi dan Bisnis, \\ Universitas Airlangga, Surabaya. \\ Email: otto.andri@gmail.com
}

\begin{abstract}
The Ministry of Tourism has made East Java province a national halal tourism development area. This is supported by the existence of various religious tourism objects, natural and artificial tourism objects, organizing annual cultural events and adequate infrastructure. The purpose of this study is to review the potential and formulate halal tourism development strategies in East Java. This study uses secondary data with qualitative methods and SWOT analysis techniques. Internal analysis shows the strengths and weaknesses as well as external analysis shows the opportunities and challenges of weakness in the development of halal tourism in East Java. Strength factors include the diversity of tourist destinations, infrastructure supporting tourist mobility, and the level of tourist visits. Weakness factors include promotion and branding, experts who are experts and means of supporting halal tourism. Opportunity factors include the support of government policies, the existence of supporting institutions, the international reputation of Indonesian halal tourism. Threat factors include economic stability, security stability and competition for the halal tourism industry. Based on the analysis of internal and external factors, the formulation of halal tourism development strategies in East Java include: a) S-O strategy: encouraging domestic and foreign investment in halal tourism development in East Java; b) W-O strategy: development of East Java halal tourism multiplatform information based on IoT; c) S-T strategy: build a halal pariwistaa halal in East Java entitled "Khazanah East Java"; d) W-T strategy: Establishment of a Special Economic Zone for Halal Tourism which is supported by the establishment of an institution of the Halal Tourism Management Authority of East Java Province
\end{abstract}

Keywords: Halal Tourism, Opportunities, Challenges, East Java 


\section{Pendahuluan}

Pariwisata adalah salah satu sektor jasa penting dalam perekonomian suatu negara. Menurut data dari Organisasi Pariwisata Dunia (UNWTO) dan Dewan Perjalanan \& Pariwisata Dunia (WTTC) pada tahun 2017, sektor pariwisata menyumbang 10\% dari Produk Domestik Bruto (PDB) global, memberikan kontribusi terhadap total ekspor dunia sebesar US $\$ 7,58$ triliun dan Pendapatan devisa di sektor Pariwisata tumbuh 25,1\%, dan pariwisata memberikan peluang kerja yang luas di mana 1 dari 11 pekerjaan berada di sektor pariwisata. ${ }^{1}$ Indonesia adalah negara yang mengandalkan sektor pariwisata untuk memberikan pertumbuhan ekonomi.

Jumlah potensi wisata Indonesia semakin ditunjukkan oleh meningkatnya jumlah kedatangan wisatawan asing dan domestik setiap tahun. Selain menetapkan target kunjungan oleh pariwisata asing dan lokal, Kementerian Pariwisata Indonesia mulai mengembangkan konsep pariwisata halal sebagai dukungan untuk Rencana Strategis Kementerian Pariwisata 20152019. ${ }^{2}$

Pengembangan wisata halal yang dilakukan oleh pemerintah didasarkan pada potensi kunjungan wisata halal itu sendiri. Belajar dari MasterCard \& CrescentRating dalam Global Muslim Travel Index 2016, pasar pariwisata halal akan menjadi salah satu segmen dengan pertumbuhan tercepat di industri pariwisata global. Pada 2015, perkiraan jumlah wisatawan Muslim global mencapai 117 dan diproyeksikan akan tumbuh menjadi 168 juta pada tahun 2020, sedangkan pengeluaran pariwisata oleh wisatawan Muslim diperkirakan akan melebihi USD 200 miliar. Perkembangan pariwisata halal juga dipengaruhi oleh permintaan yang terus meningkat seiring dengan peningkatan jumlah populasi Muslim di dunia. Berdasarkan data dari Populasi Muslim Dunia pada tahun 2014, jumlah populasi Muslim di dunia mencapai 2,38 miliar orang, setara dengan $28,26 \%$ dari total populasi di dunia. ${ }^{3}$

Kementerian Pariwisata menetapkan 13 provinsi sebagai destinasi wisata halal yang unggul. 13 provinsi termasuk Nusa Tenggara Barat (NTB), Nangroe Aceh Darussalam, Sumatra Barat, Riau, Lampung, Banten, DKI Jakarta, Jawa Barat, Jawa Tengah, Yogyakarta, Jawa Timur, Sulawesi Selatan,

\footnotetext{
1 World Tourism Organization (UNWTO). 2016. UNWTO Tourism Highlights 2016 Edition. UNWTO : Madrid. Lihat juga hasil rilis laporan dari World Travel \& Tourism Council (WTTC). 2016. Travel and Tourism EconomicImpact 2016 World. WTTC : London

2 Dadang Rizki Ratman. 2016. Pembangunan Destinasi Pariwisata Prioritas 2016-2019, dilihat 10 April 2019, http://www.kemenpar.go.id/userfiles/Paparan\%20-\%20Deputi\%20BPDIP.pdf

3 Master Card \& Crescent Rating. 2016. Global Muslim Travel Index 2016. Crescent Rating Pte. Ltd dan MasterCard Asia Pacific Pte Ltd : Singapore
}

119 | Ulumunâ: Jurnal Studi Keislaman 
dan Bali. (Andriani, 2015). Penentuan 13 provinsi adalah salah satu langkah strategis pemerintah melalui Kementerian Pariwisata dalam mempercepat Indonesia menjadi orientasi pariwisata halal dunia. Salah satu provinsi yang memiliki peluang untuk mendukung program percepatan Indonesia untuk menjadi pusat pariwisata halal di dunia adalah Provinsi Jawa Timur.

Jawa Timur adalah salah satu provinsi di Indonesia dengan keanekaragaman budaya, wisata sejarah dan wisata alam yang menarik untuk dikunjungi oleh wisatawan. Sektor pariwisata adalah salah satu sektor utama di Provinsi Jawa Timur dalam mempertahankan pertumbuhan ekonomi regional. ${ }^{4}$ Provinsi Jawa Timur merupakan daerah strategis dalam pengembangan pariwisata nasional karena berada di jalur pariwisata nasional. ${ }^{5}$ Pada tahun 2016, Kementerian Pariwisata juga menetapkan Provinsi Jawa Timur sebagai 10 prioritas pengembangan tujuan wisata terkemuka Indonesia melalui BromoTengger-Semeru. Kawasan wisata Bromo-Tengger-Semeru berada di tiga kabupaten di Jawa Timur, yaitu Kabupaten Malang, Kabupaten Pasuruan dan Kabupaten Probolinggo. ${ }^{6}$

Tabel 1. Data Kunjungan Wisatawan Domestik, Mancanegara dan PDRB Sektor Pariwisata Provinsi Jawa Timur

\begin{tabular}{|l|l|l|l|}
\hline \multirow{2}{*}{ Tahun } & \multicolumn{2}{|c|}{ Kunjungan Wisatawan } & \multirow{2}{*}{ PDRB } \\
\cline { 2 - 3 } & \multicolumn{1}{|c|}{ Domestik } & Mancanegara & \\
\hline 2012 & 33,2 juta orang & 263.943 orang & Rp 75,61 Triliun \\
\hline 2013 & 39,68 juta orang & 300.909 orang & Rp 88,16 Triliun \\
\hline 2014 & 45,6 juta orang & 463.193 orang & Rp 101,9 Trilun \\
\hline 2015 & 51,46 juta orang & 612.412 orang & Rp 92,68 Trilun \\
\hline 2016 & 55,0 juta orang & 618.536 orang & Rp 106,27 Triliun \\
\hline
\end{tabular}

Sumber : BPS Provinsi Jawa Timur (Data diolah)

Setiap tahun jumlah wisatawan domestik yang berkunjung ke Jawa Timur semakin meningkat. Hal yang sama juga terlihat pada tingkat kedatangan wisatawan asing. Sepanjang 2012 hingga 2016 jumlah kedatangan wisatawan asing di Jawa Timur cenderung meningkat. Kehadiran kunjungan wisatawan domestik dan asing di Provinsi Jawa Timur telah menyebabkan sektor pariwisata

\footnotetext{
${ }^{4}$ Badan Perencanaan Pembangunan Nasional RI. 2015. Seri Analisis Pembangunan Wilayah :ProvinsiJawaTimur,dilihat02Februari2019, http://simreg.bappenas.go.id/document/Publikasi/ DokPub/05.\%20Analisis\%20Provinsi\%20Jawa\%20Timur\%202015 ok.pdf

5 Dika Eka Lembayun. 2012. Perancangan Kawasan Wisata Pantai di Kabupaten Gresik. Tesis Ditertibkan. Pascasarjana UIN Maulana Malik Ibhrain :Malang

${ }^{6}$ Dadang Rizki Ratman. 2016. Pembangunan Destinasi Pariwisata Prioritas .........
} 
menjadi salah satu sektor pendorong pertumbuhan ekonomi daerah. Berdasarkan data BPS dari Provinsi Jawa Timur pada tahun 2016, kontribusi pariwisata terhadap perekonomian Jawa Timur selama rentang 2012-2016 telah meningkat secara dominan. Pada tahun 2012, kontribusi PDRB pariwisata mencapai 75,61 triliun dan meningkat pada 2013 dan 2014 masing-masing sebesar 88,16 triliun dan Rp 101,9 triliun. Pada 2015, PDRB pariwisata mengalami penurunan menjadi Rp 92,68 triliun, tetapi pada 2016 pariwisata PDRB mengalami peningkatan menjadi Rp 106,27 triliun.

Pengembangan pariwisata Jawa Timur mulai memimpin konsep pariwisata halal setelah ditetapkan sebagai 13 provinsi pengembangan destinasi wisata halal unggulan oleh Kementerian Pariwisata pada tahun 2015. Potensi pengembangan pariwisata halal di Provinsi Jawa Timur didukung oleh faktorfaktor termasuk: 1) Dominasi populasi Muslim, mayoritas penduduk di Jawa Timur menganut Islam. ; 2) Keragaman budaya, Provinsi Jawa Timur dikenal sebagai salah satu daerah yang kental dengan budaya Muslimnya. Sejarah perkembangan kepulauan Islam juga terkonsentrasi di Jawa Timur melalui Wali Songo; 3) Keberadaan objek wisata religius dimulai dengan pembangunan masjid bersejarah dan tempat ziarah bagi penyebar Muslim di Jawa Timur. Selain itu ada juga obyek wisata alam seperti pantai, pemandian, dan festival budaya; 4) Akomodasi dan layanan lain yang dibutuhkan oleh wisatawan seperti hotel, restoran atau restoran yang bersertifikat halal serta ketersediaan fasilitas lembaga keuangan Islam, rumah sakit Islam.

Tujuan penelitian meliputi: Untuk mengetahui gambaran umum lokasi penelitian (Provinsi Jawa Timur; Untuk mengetahui analisis faktor internal dan eksternal dalam pengembangan pariwisata halal di Jawa Timur; Untuk mengetahui bagaimana rumusan strategi dalam pengembangan pariwisata halal

Penelitian ini, jenis desain penelitian yang digunakan adalah penelitian eksploratif dengan penelitian kualitatif. Penelitian eksplorasi adalah desain penelitian yang mengeksplorasi atau mencari masalah atau situasi untuk mendapatkan wawasan dan pemahaman. ${ }^{7}$ Penelitian kualitatif, data kualitatif adalah data dalam bentuk kata-kata, skema, dan gambar. ${ }^{8}$ Tujuan dari menggunakan desain penelitian eksplorasi dan jenis penelitian kualitatif adalah untuk memberikan wawasan dan pemahaman tentang potensi dan strategi pengembangan pariwisata halal di Provinsi Jawa Timur.

Jenis data yang digunakan dalam penelitian ini adalah data sekunder. Data yang diperoleh dari data sekunder adalah dokumen resmi dari Pemerintah

\footnotetext{
${ }^{7}$ Naresh K Malhotra dan David F. Briks. 2006. Marketing Research : An Applied Approach. United Kingdom : Pearson Education Ltd h. 49

${ }^{8}$ Sugiyono. 2013. Metode Penelitian Kuantitatif Kualitatif dan R \& D. Bandung: Alfabeta h. 79

$121 \mid$ Ulumunâ: Jurnal Studi Keislaman
} 
Pusat dan Provinsi Jawa Timur, terutama mengenai pariwisata, jurnal penelitian, buku dan artikel yang berkaitan dengan pariwisata, terutama pariwisata halal. Metode pengumpulan data dalam penelitian ini adalah studi literatur. Studi literatur dalam pengumpulan data adalah jenis data sekunder yang digunakan untuk membantu proses penelitian, yaitu dengan mengumpulkan informasi yang terkandung dalam artikel surat kabar, buku, dan karya ilmiah dalam penelitian sebelumnya. Tujuan dari studi literatur ini adalah untuk menemukan fakta dan mengetahui konsep metode yang digunakan.

Metode analisis data yang digunakan dalam penelitian ini adalah Analisis SWOT. Analisis SWOT adalah pendekatan yang bertujuan untuk membantu organisasi dalam mempertimbangkan dengan hati-hati kemampuan internal organisasi dan menggunakan hasilnya untuk membentuk pilihan strategis. Analisis SWOT mempertimbangkan kekuatan, kelemahan, peluang, dan ancaman organisasi. Dengan menggunakan analisis SWOT, organisasi dapat memilih strategi yang mendukung misinya dan memanfaatkan peluang dan kekuatannya, serta menetralisir ancamannya dan menghindari kelemahannya. ${ }^{9}$

\section{Analisis Faktor Eksternal dan Internal dalam Pengembangan Pariwisata Halal Jawa Timur}

Analisis Eksternal

a. Kesempatan

1. Dukungan kebijakan pemerintah pusat dan daerah

Kementerian Pariwisata telah menetapkan 13 provinsi sebagai tujuan wisata halal terkemuka, termasuk provinsi Jawa Timur. Penentuan kawasan tersebut merupakan bagian dari target pemerintah untuk menjadikan Indonesia sebagai pusat pariwisata pariwisata global. ${ }^{10}$ Provinsi Jawa Timur mendukung penuh program dengan mengembangkan pariwisata halal di beberapa kota kabupaten. Awal 2017 adalah momentum Dinas Kebudayaan dan Pariwisata Kota Malang dalam mengembangkan pariwisata halal. ${ }^{11}$

Selain Kota Malang, Pemerintah Kabupaten Pasuruan juga mulai mencari pengembangan pariwisata halal. Pemerintah Kabupaten Pasuruan didasarkan pada keberadaan destinasi wisata yang cukup lengkap, yaitu wisata

\footnotetext{
9 Freddy Rangkuti. 2015. Analisis SWOT : Teknik Membedah Kasus Bisnis. Gramedia Pustaka Utama. Jakarta h. 23

${ }^{10}$ Dini Andriani. 2015. Kajian Pengembangan Wisata Syariah. Kementrian Pariwisata : Jakarta

${ }^{11}$ Andi Hartik. 2016. Awal Tabun 2017, Kota Malang Targetkan Jadi Destinasi Wisata Halal, dilihat12

Februari2019,http://travel.kompas.com/read/2016/09/01/211500927/Awal.Tahun.2017.Ko ta.Malang.Targetkan.Jadi.Destinasi.Wisata.Halal
} 
alam gunung, air terjun, pemandian umum, danau, wisata keluarga, wisata religius dan sejarah serta kuliner. ${ }^{12}$

Badan Pengembangan Daerah Madura Surabaya (BPWS) juga akan berencana mengembangkan pariwisata halal di Pulau Madura. Menurut BPWS, fokus pengembangan pariwisata halal di Pulau Madura adalah pariwisata Islam. Ini disesuaikan dengan kondisi sosial komunitas agama Madura, di mana 90\% populasi di Pulau Madura memeluk Islam. Potensi pengembangan wisata syariah di Pulau Madura juga terlihat pada akulturasi budaya lokal yang telah dipengaruhi oleh ajaran agama Islam dan keberadaan objek wisata religius mulai dari masjid dan istana kesultanan di Pulau Madura. ${ }^{13}$

2. Adanya lembaga sertifikasi halal dan / atau syariah untuk mendukung fasilitas wisata halal

Sertifikasi bisnis pariwisata halal telah diatur dalam Peraturan Menteri Pariwisata Republik Indonesia Nomor 1 Tahun 2016 tentang Penerapan Sertifikasi Bisnis Pariwisata. dalam peraturan tersebut, Sertifikasi Bisnis Pariwisata Halal dilaksanakan oleh Dewan Syariah Nasional - Majelis Ulama Indonesia DSN-MUI mengeluarkan sertifikasi kesesuaian syariah dengan entitas bisnis, salah satunya adalah sertifikasi hotel. Setiap hotel yang akan menerapkan layanan berbasis syariah harus mendapatkan sertifikasi kesesuaian syariah dari DSN-MUI.

Selain MUI, lembaga non-pemerintah yang dapat mendukung pengembangan pariwisata halal juga ditemukan di Jawa Timur, yaitu Yayasan Halalan Thoyyiban Indonesia yang berlokasi di Kota Batu. Yayasan ini bertujuan untuk mewujudkan konsumen pintar, produsen yang bertanggung jawab berdasarkan halal dan thoyyib. Kegiatan di Yayasan Halalan Thoyyiban Indonesia meliputi penelitian terpadu berdasarkan halal dan thoyyib, pengabdian masyarakat, rekomendasi kepada para pemangku kepentingan. Selain itu, pengembangan pariwisata halal di Jawa Timur juga didukung melalui keberadaan pusat studi halal di perguruan tinggi seperti Pusat Halal Universitas Airlangga.

3. Reputasi pariwisata halal Indonesia di tingkat internasional

\footnotetext{
12 Andi. 2017. 2018, Pasuruan Fokus Kembangkan Wisata Halal, dilihat20 Februari2019,http://travel.kompas.com/read/2016/04/11/172500627/2018.Pasuruan.Fokus Kembangkan. Wisata.Halal

13 Citra Fitri Mardiana. 2017. Pulau Madura Bakal Punya Wisata Berbasis Syariah, dilihat 01 April 2019, https:// finance.detik.com/berita-ekonomi-bisnis/3580526/pulau-madura-bakal-punyawisata-berbasis-syariah
}

123 | Ulumunâ: Jurnal Studi Keislaman 
Pariwisata halal di Indonesia telah menerima pengakuan dalam Penghargaan Pariwisata Halal Dunia selama dua tahun terakhir, yaitu 2015 dan 2016. Penghargaan ini merupakan bentuk pengakuan internasional terhadap potensi dan pesona pariwisata Halal Indonesia. Indonesia menerima tiga penghargaan dalam Penghargaan Pariwisata Halal Dunia 2015, Destinasi Wisata Halal Terbaik Dunia (Lombok), Destinasi Bulan Madu Halal Terbaik Dunia (Lombok), dan Hotel Ramah Keluarga Terbaik Dunia (Hotel Sofyan). Sementara di ajang World Halal Tourism Award 2016, Indonesia menerima 12 kategori penghargaan dari 16 kategori. 12 kategori penghargaan meliputi: 1) Maskapai Penerbangan Terbaik Dunia untuk Pelancong Halal: Garuda Indonesia; 2) Bandara Terbaik Dunia untuk Wisatawan Halal: Bandara Internasional Sultan Iskandar Muda (Aceh); 3) Hotel Ramah Keluarga Terbaik Dunia: The Rhadana Kuta, Bali; 4) Hotel Ramah Keluarga Paling Mewah di Dunia: The Trans Luxury Hotel, Bandung; 5) Resor Pantai Halal Terbaik Dunia: Novotel Lombok Resort \& Villas; 6) Operator Tur Halal Terbaik Dunia: Tur ERO, Sumatera Barat; 7) Situs Web Travel Halal Terbaik Dunia: www.wonderfullomboksumbawa.com; 8) Tujuan Bulan Madu Halal Terbaik di Dunia: Wilayah Lembah Sembalun, Nusa Tenggara Barat; 9) Operator Haji \& Umrah Terbaik Dunia: ESQ Tours \& Travel; 10) Destinasi Halal Terbaik Dunia: Sumatra Barat; 11) Destinasi Kuliner Halal Terbaik Dunia: Sumatra Barat; 12) Destinasi Budaya Halal Terbaik Dunia: Aceh. ${ }^{14}$

b. Ancaman

1. Stabilitas ekonomi regional, nasional, provinsi, internasional dan global.

2. Stabilitas keamanan dalam dan luar negeri.

3. Persaingan antar wilayah dan negara dalam pengembangan pariwisata halal

Analisis Internal

a. Kekuasaan

1. Keanekaragaman tujuan wisata di Provinsi Jawa Timur

Popularitas tujuan wisata di Provinsi Jawa Timur tersebar di 29 kabupaten dan 9 wilayah perkotaan. Setiap tujuan wisata di Jawa Timur menawarkan tempat wisata yang unik, menarik dan sarat dengan budaya Jawa Timur yang khas. Objek wisata Provinsi Jawa Timur terbilang lengkap mulai

\footnotetext{
14 National Geographic Indonesia. 2016. Indonesia Raih 12 Penghargaan Bergengsi di Ajang The World Halal Tourism Awards 2016, dilihat 12 Februari 2019, http://nationalgeographic.co.id/berita/2016/12/indonesia-raih-12-penghargaan bergengsi-diajang-the-world-halal-tourism-awards-2016
} 
dari wisata alam, wisata budaya, wisata belanja, wisata olahraga, dan wisata buatan.

2. Mendukung Mobilitas Infrastruktur

Infrastruktur pendukung untuk mobilitas wisatawan di Jawa Timur cukup lengkap mulai dari pilihan moda transportasi darat, laut dan udara. Semua kabupaten dan kota di Jawa Timur telah terhubung melalui infrastruktur transportasi darat baik melalui jalan darat maupun kereta api. Moda transportasi lain yang dapat digunakan oleh wisatawan adalah udara dan laut.

3. Tingkat kunjungan wisatawan domestik dan asing di Provinsi Jawa Timur Berdasarkan data dari hasil Survei Profil Wisata Nusantara selama 2012-2016, jumlah wisatawan domestik yang melakukan perjalanan ke Provinsi Jawa Timur adalah yang tertinggi di antara 34 provinsi di Indonesia. Menurut data BPS, setiap tahun jumlah wisatawan domestik yang berkunjung ke Jawa Timur mencapai puluhan juta orang. Rata-rata lama menginap tamu (RLMT) wisatawan domestik di semua hotel di Provinsi Jawa Timur adalah 1 hingga 2 hari.

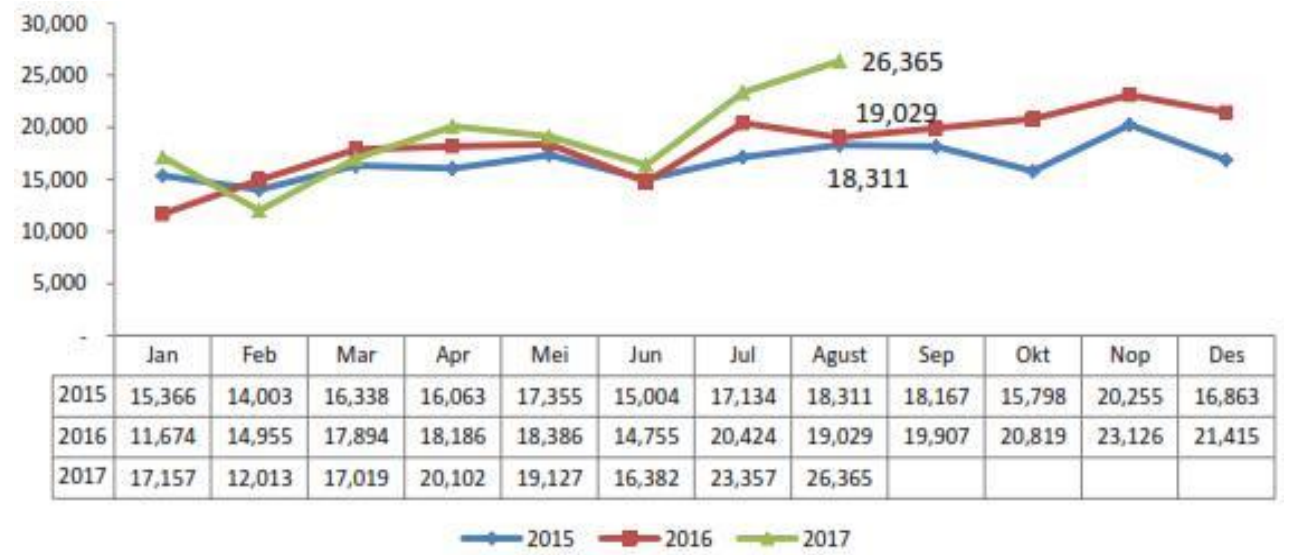

Sumber : BPS Provinsi Jawa Timur (2017)

Gambar 4. Grafik Jumlah Wisatawan Mancanegara yang Datang ke Jawa Timur Melalui Pintu Masuk Juanda Tahun 2015-2017

Perjalanan wisatawan asing ke Jawa Timur berada di peringkat kelima setelah Bali, Jakarta, Batam dan Medan berdasarkan jumlah kedatangan wisatawan asing sesuai dengan pintu masuk. Kunjungan wisatawan asing di Provinsi Jawa Timur melalui pintu masuk Juanda selama 2015 hingga Agustus 2017 menunjukkan peningkatan. Menurut data BPS dari Jawa Timur, jumlah kedatangan wisatawan asing dari Januari hingga Agustus 2017 
mencapai 151.522 kunjungan, meningkat 11,99 persen dibandingkan dengan jumlah wisatawan asing pada periode yang sama tahun 2016 yang mencapai 135.303 kunjungan. Negara asal turis asing paling banyak mengunjungi Jawa Timur adalah Malaysia, kemudian Singapura dan Cina. Rata-Rata Lama Menginap Tamu (RLMT) wisatawan asing di hotel bintang 2 hingga 3 hari. b. Kelemahan

1. Promosi dan branding pariwisata halal di Jawa Timur

Pengembangan pariwisata halal di Jawa Timur masih dihadapkan pada masalah promosi. Menurut Arby kurangnya promosi dari pemain industri pariwisata telah menyebabkan pariwisata halal di Indonesia mandek dan tertinggal dari negara-negara Muslim lainnya. ${ }^{15}$ Kelemahan lain yang menghambat pengembangan pariwisata halal di Jawa Timur adalah peran industri jasa pariwisata lokal. Penelitian Andriani juga menjelaskan bahwa masalah lain adalah bahwa tidak banyak biro perjalanan telah mengemas perjalanan masuk dengan paket perjalanan halal di Indonesia, tetapi lebih banyak kemasan untuk perjalanan keluar seperti umrah dan haji. ${ }^{16}$ Mayoritas bisnis wisata dan perjalanan di Jawa Timur hanya menyediakan paket wisata tanpa mempertimbangkan aspek halal selama tur, seperti pemilihan akomodasi hotel yang tidak bersertifikat syariah untuk wisatawan Muslim.

2. Sarana untuk mendukung pariwisata halal

Metode pendukung seperti hotel syariah adalah hal terpenting dalam pengembangan pariwisata halal di Jawa Timur. Secara nasional, jumlah hotel syariah yang disertifikasi oleh MUI adalah 37 hotel dari 9.812 hotel di Indonesia. Jumlah minimum hotel khusus syariah bersertifikat di Jawa Timur disebabkan oleh tingginya biaya investasi untuk hotel syariah karena penambahan beberapa fasilitas dari berbagai aspek yang sesuai dengan peluncuran Kementerian Pariwisata dan MUI. ${ }^{17}$

3. Sumber daya manusia yang ahli dalam pariwisata halal

Keramahtamahan lainnya dalam pengembangan pariwisata halal di Jawa Timur adalah ketersediaan sumber daya manusia yang ahli di bidang pariwisata halal. Sejauh ini, baik universitas negeri maupun swasta di Jawa

\footnotetext{
15Ikhsan Arby. 2012. Mengapa ada Fakultas Pariwisata di UMSB?. (online) https://www.academia.edu/5841658/Wisata Syariah Halal Tourism, diakses 05 Februari 2019

${ }^{16}$ Dini Andriani. 2015. Kajian Pengembangan Wisata Syariah. Kementrian Pariwisata : Jakarta. h. 87

${ }^{17}$ Irwan Kelana. 2015. Hotel Syariah Terkendala Investasi, dilihat 10 April 2019, http://www.republika.co.id/berita/koran/syariah-koran/15/01/09/nhwmgm5-hotel-syariahterkendala-investasi
} 
Timur yang menawarkan program studi atau program pariwisata tidak memiliki konsentrasi pariwisata halal. Sebagai contoh dari kurikulum program studi (S1) bisnis pariwisata di Universitas Brawijaya tidak memiliki kursus khusus tentang pariwisata halal. Hal yang sama ditemukan dalam kurikulum program studi vokasi Pariwisata di Fakultas Vokasi Universitas Airlangga.

Perumusan Strategi Pengembangan Pariwisata Halal Jawa Timur Tabel 3. Matrix SWOT

\begin{tabular}{|c|c|c|}
\hline EFAS & $\begin{array}{l}\text { wisatawan domestik } \\
\text { dan mancanegara di } \\
\text { Provinsi Jawa Timur }\end{array}$ & \\
\hline Peluang/Opportunites $(\mathrm{O})$ & Strategi S-O & Strategi W-O \\
\hline 1. Dukungan kebijakan & Mendorong investasi & Pengembangan \\
\hline pemerintah pusat dan & dalam pengembangan & $\begin{array}{l}\text { Multiplatform } \\
\text { Informasi } \\
\text { Pariwisata Halal }\end{array}$ \\
\hline daerah & sarana pendukung & Jawa \\
\hline 2. Keberadaan lembaga & pariwisata halal Jawa & $\begin{array}{l}\text { 1imur berbasis } \\
\text { Internet of }\end{array}$ \\
\hline $\begin{array}{l}\text { sertifikasi halal dan atau } \\
\text { syariah untuk sarana } \\
\text { penunjang pariwisata halal }\end{array}$ & Rimur & Things (IoT) \\
\hline 3. Reputasi pariwisata halal & & \\
\hline $\begin{array}{l}\text { Indonesia ditingkat } \\
\text { internasional }\end{array}$ & & \\
\hline Ancaman/Threats $(\mathrm{T})$ & Strategi S-T & $\begin{array}{l}\text { Strategi W-T } \\
\text { Penguatan }\end{array}$ \\
\hline 1. Stabilitas ekonomi & Membangun branding & kelembagaan \\
\hline daerah, nasional, & pariwisata halal Jawa & $\begin{array}{l}\text { melalui } \\
\text { pembentukan } \\
\text { Badan Otorita }\end{array}$ \\
\hline regional, internasional & Timur bertajuk & $\begin{array}{l}\text { Pengelola } \\
\text { Pariwisata Halal }\end{array}$ \\
\hline dan global & "Khazanah Jawa Timur" & Provinsi \\
\hline $\begin{array}{l}\text { 2. Stabilitas kemanan } \\
\text { dalam dan luar negeri }\end{array}$ & & Jawa Timur \\
\hline 3. Persaingan antar daerah & & \\
\hline
\end{tabular}


dan negara dalam

pengembangan

pariwisata halal

\section{Strategi yang Lahir}

Untuk bisa menjaga pariwisata syariah agar selalu dikenal dan dapat menjadi daya tarik tersendiri, maka dibutuhkan beberapa strategi yang jitu agar selalu dapat mengembangkan pariwisata syariah di Jawa Timur, bahkan se-Indonesia. Oleh karena itu, tawaran beberapa strategi yang dianggap penting untuk dapat menjaga eksistensi pariwisata syariah yaitu

1. Melahirkan Duta Pariwisata Syariah

Dengan adanya Duta pariwisata syariah sebagai media untuk memperkenalkan item wisata, maka diharapkan Pariwisata Syariah yang lahir dapat memperluas cakupannya, bahkan sudah memiliki item pariwisata syariah se-Provinsi.

2. Melaksanakan Sertifikasi Halal dan Thoyyiban

Diperlukan dukungan Kementerian Pariwisata, Badan Ekonomi Kreatif dan Majelis Ulama Indonesia (MUI) untuk dapat menciptakan sertifikasi halal bagi item wisata syariah yang lahir.

3. Menciptakan Kreativitas untuk Produk Kuliner

Dengan adanya SDM yang berkompeten, produk kuliner yang sudah ada pun dapat dikreasikan tanpa harus menghilangkan ke-khas-an dan nilai dari suatu produk tersebut.

4. Membuat "Daerah Percontohan" Pariwisata Syariah

Strategi ini merupakan hal yang sangat dibutuhkan dan penting sebagai wadah awal untuk mewujudkan dan mengembangkan pariwisata syariah.

5. Memanfaatkan semua Media yang ada.

Media sosial, media elektronik, maupun media massa diharapkan dapat mendukung sosialisasi pariwisata syariah yang merupakan salah satu item dari Pariwisata dan Ekonomi Kreatif.

6. Membuat "Manual Tour Guide" khusus pariwisata syariah

Dengan adanya panduan manual ini, diharapkan dapat memperkenalkan hal-hal yang bersifat syar'i ketika sedang melakukan wisata syariah.

7. Men-Syiar-Kan Dampak Negatif "Item Pariwisata" Yang Tidak Syar'i Dengan mengetahui dampak negatif dari item pariwisata yang tidak syar'i, diharapkan dapat memberikan edukasi wisatawan terkait pariwisata syariah dan non-syariah. 
8. Membuat Jurusan Pariwisata Syariah

Hal ini dilakukan dalam rangka menciptakan SDM yang handal dalam mengelolah pariwisata syariah.

\section{Kesimpulan}

Pengembangan pariwisata halal di Jawa Timur merupakan salah satu strategi dalam menjadikan sektor pariwisata sebagai mesin ekonomi Jawa Timur. Pengembangan wisata halal di Jawa Timur didukung oleh potensi seperti kearifan lokal yang berkembang dan dipengaruhi oleh Islam, keberadaan objek wisata religi, alam dan buatan serta aksesibilitas dan fasilitas pendukung lainnya. Berdasarkan hasil analisis diagram SWOT, pariwisata halal di Jawa Timur ada pada diagram 1, yang berarti memiliki potensi untuk dikembangkan. Pengembangan pariwisata halal di Jawa Timur memerlukan beberapa strategi, termasuk: 1) mendorong investasi domestik dan asing dalam pengembangan pariwisata halal di Jawa Timur; 2) mengembangkan multi-platform pusat informasi halal pariwisata Jawa Timur berdasarkan IoT; 3) desain branding berjudul "Khazanah Jawa Timur" yang digabungkan dengan implementasi acara Islam kelas dunia yang menampilkan budaya Islam nusantara; 4) pembentukan otoritas pengelolaan pariwisata halal pariwisata Jawa Timur. Pengembangan strategi ini diharapkan dapat mengoptimalkan potensi wisata halal Jawa Timur untuk menjadi salah satu tujuan wisata halal terkemuka di Indonesia yang dapat bersaing dengan negara-negara di dunia. Selain itu, keberadaan halal pariwisata Jawa Timur akan mendukung percepatan Indonesia sebagai pusat pariwisata halal dunia.

\section{DAFTAR PUSTAKA}

Alim, Haidar Tsany et al. 2014. Analisis Potensi Parinisata Syariah DenganMengoptimalkan Industri Kreatif Di Jawa Tengah dan Yogyakarta, dilihat12Februari2019, http://eprints.undip.ac.id/45828/1/Artikel.pf

Andi. 2017. 2018, Pasuruan Fokus Kembangkan Wisata Halal,dilihat $20 \quad$ Februari 2019, http://travel.kompas.com/read/2016/04/11/172500627/2018.Pasu ruan.Fo kus.Kembangkan.Wisata.Halal

Andriani,Dini. 2015. Kajian Pengembangan Wisata Syariah. Kementrian Pariwisata : Jakarta

Arby, Ikhsan. 2012. Mengapa ada Fakultas Pariwisata di UMSB?. (online) https://www.academia.edu/5841658/Wisata Syariah Halal Touris $\underline{\mathrm{m}}$, diakses 05 Februari 2019 
Artik, Andi. 2016. Awal Tahun 2017, Kota Malang Targetkan Jadi Destinasi Wisata Halal, dilihat 12 Februari 2019, http://travel.kompas.com/read/2016/09/01/211500927/Awal.Tah un.2017.Kota.Malang.Targetkan.Jadi.Destinasi.Wisata.Halal

Astutik, Kurnia Fami dan Sarmini. 2014. Budaya Kerapan Sapi Sebagai Modal Sosial Masyarakat Madura Di Kecamatan Sepulu Kabupaten Bangkalan. Jurnal Kajian Moral dan Kewarganegaraan Nomor 1 Volume 3

Badan Koordinasi Penanaman Modal. 2017. Gelar RIF 2017, BKPM FokusTingkatkan Investasi Pariwisata dan Infrastruktur Pendukung, dilihat 01 April 2019, http://www2.bkpm.go.id/images/uploads/file_siaran_pers/Siaran_ Pers_BKPM_170017_Gelar_RIF\%2C_BKPM_Fokus_Tingkatkan_I nvestasi_Pari wisata.pdf

Badan Perencanaan Pembangunan Daerah Provinsi Jawa Timur. 2015. Buku DataDinamis Provinsi Jawa Timur. BAPPEDA Jawa Timur : Surabaya

Badan Perencanaan Pembangunan Nasional RI. 2015. Seri Analisis PembangunanWilayah : Provinsi Jawa Timur, dilihat 02 Februari 2019, http://simreg.bappenas.go.id/document/Publikasi/DokPub/05.\%2 0Analisis $\% 20$ Provinsi $\% 20$ Jawa $\% 20$ Timur $\% 202015$ ok.pdf

Badan Pusat Statistik. 2016. Jumlah Kedatangan Wisatawan Mancanegara dan Domestik. BPS : Jakarta

Badan Pusat Statistik Provinsi Jawa Timur. 2013. Perkembangan Pariwisata Jawa Timur, dilihat 12 Februari 2019, https://jatim.bps.go.id/4dm!n/brs ind/brsInd-20131201024220.pdf

Badan Pusat Statistik Provinsi Jawa Timur. 2017. Pertumbuban Ekonomi Jawa Timur Tabun 2016, dilihat 23 Februari 2019, https://jatim.bps.go.id/4dm!n/brs ind/brsInd20170213080331.pdf

Chookaew, S et al. 2015. Increasing Halal Tourism Potential at Andaman Gulf in. Journal of Economics, Business and Management, Vol 3 No 7 Hal. 277279.

BuzzCity. 2016. The BuгzCity Report: A Quarterly Briefing On The Mobile Internet, dilihat 12 Februari 2019, http://www.buzzcity.com/1/reports/TheBuzzCity-Report-Vol-6-Issue-2.pdf

Fakultas Vokasi Univeristas Airlangga. 2016. Tentang Program Studi D3 Kepariwisataan, dilihat 05 April 2019, http://www.unair.ac.id/site/article/read/107/d3kepariwisataan.html 
Ghofar, Abdul. 1999. Analsis Implikasi Pemikiran dan Penafsiran Akuntansi dariParadigma Mainstream Barat dan Paradigma Islam dalam Kerangka Analisis Konsep TAO (Studi KualitatifKomparatif Akuntansi Mainstream dan Akuntansi Alternatif dalam Pembentukan Akuntansi Humanis. Skripsi (S1). Jurusan Akuntansi, Fakultas Ekonomi,Universitas Brawijaya, Malang

Hasan, Ali. 2013. Marketing Dan Kasus-Kasus Pilihan. Yogyakarta: Caps

Ismayanti. 2010. Pengantar Pariwisata. Jakarta: PT Gramedia Widisarana

Istijanto . 2006. Riset Sumber Daya Manusia. Jakarta : PT. Gramedia PustakaUtama

Kelana, Irwan. 2015. Hotel Syariah Terkendala Investasi, dilihat 10 April 2019, http://www.republika.co.id/berita/koran/syariah-

koran/15/01/09/nhwmgm5-hotel-syariah-terkendala-investasi

Lembayun, Dika Eka. 2012. Perancangan Kawasan Wisata Pantai di Kabupaten Gresi. Tesis Ditertibkan. Pascasarjana UIN Maulana Malik Ibhrain :Malang

Malhotra, Naresh K. 2015. Essentials of Marketing Research : A Hands-On Orientation. United Kingdom : Pearson Education Ltd

Malhotra, Naresh K dan David F. Briks. 2006. Marketing Research : An Applied Approach. United Kingdom : Pearson Education Ltd

Mardiana, Citra Fitri. 2017. Pulau Madura Bakal Punya Wisata Berbasis Syariah, dilihat 01 April 2019, https://finance.detik.com/berita-ekonomibisnis/3580526/pulau-madura-bakal-punya-wisata-berbasis-syariah

Master Card \& Crescent Rating. 2016. Global Muslim Travel Index 2016. CrescentRating Pte. Ltd dan MasterCard Asia Pacific Pte Ltd : Singapore

Moeloeng, Lexy J. 2004. Metodologi Penelitian Kualitatif. PT. Remaja Rosdakarya : Bandung

Martono, Nanang. 2011. Metode Penelitian Kuantitatif. Jakarta: PT Raya Grafindo Persada.

Murwandani, Nunuk Giari. 2007. Arsitektur-Interior Keraton Sumenep Sebagai Wujud Komunikasi Dan Akulturasi Budaya Madura, Cina Dan Belanda. Jurnal DIMENSI INTERIOR, VOL. 5, NO. 2

National Geographic Indonesia. 2016. Indonesia Raih 12 Penghargaan Bergengsi di Ajang The World Halal Tourism Awards 2016, dilihat 12 Februari 2019, http://nationalgeographic.co.id/berita/2016/12/indonesia-raih-12penghargaan bergengsi-di-ajang-the-world-halal-tourism-awards-2016

Nizar, Muhammad Afdi. 2015. Pengarub Pariwisata terhadap PerdaganganInternasional di Indonesia, dilihat 10 April 2019, 
https://www.kemenkeu.go.id/sites/default/files/Hubungan\%20Pari wisata $\% 20$ Dan $\% 20$ Perdagangan $\% 20$ Internasional.pdf

Prodjo, Wahyu Adityo. 2017. Status Awas Gunung Agung, 5 Negara PerbaruiTravel Advice ke Indonesia, dilihat 01 April 2019, http://travel.kompas.com/read/2017/09/25/074100027/statusawas-gunung-agung-5-negara-perbarui-travel-advice-ke-indonesia

Ratman, Dadang Rizki. 2016. Pembangunan Destinasi Pariwisata Prioritas 20162019, dilihat 10 April 2019, http://www.kemenpar.go.id/userfiles/Paparan $\% 20$ $\% 20$ Deputi $\% 20$ BPDIP.pdf

Rangkuti, Freddy.2015. Analisis SWOT: Teknik Membedah Kasus Bisnis. Gramedia Pustaka Utama. Jakarta

Rizka, R. 2016. Persepsi Konsumen Tentang Wisata Syariah Dan PengarubnyaTerhadap Minat Berkunjung. Skripsi (S1). Jurusan Administrasi Bisnis,FISIP, Universitas Lampung, Bandar Lampung

Sari, Yonita Prateka dan F. Anita Herawati. 2013. Pengarub Terpaan Informasi Melalui Internet tentang Pariwisata Terhadap Motivasi Penggemar Traveling Berkunjung ke Yogyakarta, dilihat 17 April 2019, http://ejournal.uajy.ac.id/4286/

Soebagyo. 2012. Strategi Pengembangan Pariwisata di Indonesia. Jurnal Liquidity Vol 1 No 2, hal 154

Sosilawati et al. 2016. Sinkronisasi Program dan Pembiayaan PembangunanJangka Pendek. 2018-2020 Keterpaduan Pengembangan Kawasan dengan Infrastruktur PUPR Pulau Jawa, Volume 1. KementerianPekerjaan Umum Dan Perumahan Rakyat : Jakarta

State of The Global Islamic Economy. 2016. State of The Global IslamicEconomy Report 2015/16. Thomson Reuters : New York City

Sugiyono. 2013. Metode Penelitian Kuantitatif Kualitatif dan R \& D. Bandung: Alfabeta

Syaikh Salim bin 'Ted al-Hilali. 2005. Syarah Riyadhush Shalibin Jilid 4. Pustaka Imam As-Syafi'i : Jakarta.

Suherlan, Ade. 2015. Persepsi Masyarakat Jakarta Terhadap Islamic Tourism.

TheJournal of Taubidinomics Vol. 1 No. 1, hal 62

Tim Penulis Universitas Negeri Malang. 2000. Pedoman Penulisan Karya Ilmiah:Skripsi, Tesis, Disertasi, Laporan Penelitian, Artikel, dan Makalah.Universitas Negeri Malang : Malang

Utama, I Gusti Bagus Rai. 2010. Pariwisata dalam pandangan Islam dan Muslim. Working Paper for Cultural Study. Universitas Dhyana Pura Bali 
Zanuardi, Arfian. 2016. Pembangunan Infrastruktur dalam PengembanganWilayah Pulau Madura. Tugas Individu. Fakultas Teknik Sipil danPerencanaan, Institut Teknologi Sepuluh Nopember : Surabaya

World Economic Forum. 2017. The Travel \& Tourism Competitiveness Report2017. WEF : Geneva

World Muslim Population. 2014. Wolrdwide Moslem Poplation, diakses 26 Februari 2019, http://www.muslimpopulation.com/World/

World Tourism Organization (UNWTO). 2016. UNWTO Tourism Highlights 2016 Edition. UNWTO : Madrid.

World Travel \& Tourism Council (WTTC). 2016. Travel and Tourism EconomicImpact 2016 World. WTTC : London

Yudananto, Wisnu et al. 2012. Peranan Sektor Pariwisata Terhadap Perekonomian Daerah Di Indonesia (Analisis Interregional Inputoutput), dilihat 12 Februari 2019, http://repository.unpad.ac.id/15054/1/pustaka unpad peranan sek tor pariwisata.pdf

Zuraya, Nadia. 2017. AS dan Australia Keluarkan Travel Warning ke Indonesia, dilihat 12 Februari 2019, http://www.republika.co.id/berita/internasional/global/17/05/26/oqja6z383 -as-dan-australia-keluarkan-travel-warning-ke-indonesia 